\title{
PENYULUHAN PENDIDIKAN KARAKTER SEBAGAI PILAR DALAM MEMBANGUN MORAL DAN AKHLAK ANAK
}

\author{
(Character Education Education As Pillar In Moral Building And Children Children) \\ Muhammad Tri Ramdhani, Supriadi dan Hunainah
}

Program Studi Pendidikan Agama Islam Fakultas Agama Islam

Universitas Muhammadiyah Palangkaraya

JI. RTA Milono Km.1,5 Palangka Raya, Kalimantan Tengah 73111

e-mail : muhammadtriramdhani@gmail.com, adianstercool@yahoo.com, Hunzie84@gmail.com

\begin{abstract}
At this time character education can no longer be ignored because of the role that is very important to improve the moral and morals of children, because the moral children of today's nation is getting away from the good word with the modern era of changes that are cultivated in information technology that is growing rapidly renewal. Based on the above description it is considered necessary to conduct character education counseling activities as a pillar in building moral and morals of children in the community around Palangkaraya, especially the area around PKBM Luthfillah in kel. Pahandut still lack of knowledge about general education, religion, and lack of awareness of the importance of character education so maih mostly found from small children and adolescents who do not have a formal education or equivalency education.

In this PKM activity, to overcome the apparent problems, the team of lecturers Prodi PAI offers PKM implementation with the form of Character Education Education as a Pillar in Building Moral And Child Morals held at PKBM Luthfillah, which is opened for PKBM and general participants.

Considering many people who do not have formal education or equality, this counseling is expected to be useful and equip the community about understanding the guidance of Islam in educating children at home in general and about the procedures for the implementation of personal Islamic character education that can be maximally endeavored by each family members, both the head of the family and the representatives and all their members, so as to assist the government in socializing character education for the grass root community in practice level.
\end{abstract}

Keywords : character education, moral building and morals of children

\section{Abstrak}

Pada saat ini pendidikan karakter tidak bisa lagi untuk tidak diindahkan keberadaannya karena peran yang sangat penting untuk memperbaiki moral dan akhlak anak, karena moral anak bangsa saat ini semakin jauh dari kata baik dengan teriringnya zaman modern yang penuh digeluti teknologi informasi yang semakin hari berkembang pesat terus adanya perbaharuan. Berdasarkan uraian di atas dipertimbangkan perlu diadakan kegiatan penyuluhan pendidikan karakter sebagai pilar dalam membangun moral dan akhlak anak di masyarakat sekitar Palangkaraya, terutama wilayah sekitar PKBM Luthfillah di kel. Pahandut yang masih minim pengetahuan mengenai pendidikan umum, agama, dan minimnya kesadaran akan pentingnya pendidikan karakter sehingga maih banyak ditemukan dari anak-anak kecil dan remaja yang tidak mengenyam pendidikan formal ataupun pendidikan kesetaraan.

Dalam kegiatan PKM kali ini, untuk mengatasi permasalahan yang tampak, tim Dosen Prodi PAI menawarkan pelaksanaan PKM dengan bentuk Penyuluhan Pendidikan Karakter Sebagai Pilar Dalam Membangun Moral Dan Akhlak Anak yang diadakan di PKBM Luthfillah, yang dibuka untuk peserta PKBM dan umum.

Mengingat banyak masyarakat yang tidak mengenyam pendidikan formal ataupun kesetaraan, maka penyuluhan ini diharapkan bisa bermanfaat dan membekali masyarakat sekitar mengenai pemahaman akan tuntunan Islam dalam mendidik anak di rumah secara umum dan mengenai tata cara pelaksanaan pendidikan karakter Islami secara personal yang dapat diupayakan secara maksimal oleh tiap anggota keluarga, baik kepala keluarga maupun wakil dan seluruh anggotanya, sehingga dapat membantu pemerintah dalam mensosialisasikan pendidikan karakter bagi masyarakat grass root dalam tataran praktek.

Kata Kunci : pendidikan karakter, membangun moral dan akhlak anak 


\section{PENDAHULUAN}

Melihat kasus di Indonesia terjadinya beberapa dekadensi moral yaitu krisis akhlak. Akar praktik kolusi-nepotisme adalah kuatnya tradisi anak penguasa yang selalu mendapat kemudahan berusaha karena jaringan kekuasaan yang dibangun oleh orangtua mereka. (Mansyur Semma: 2008, 25). Seiring dengan kemajuan ilmu pengetahuan dan teknologi dewasa ini, banyak orangtua yang mengabaikan pendidikan karakter bagi anak-anaknya. Tuntutan zaman menyebabkan para orangtua cenderung memberi perhatian lebih pada pendidikan fisik dan intelijen saja (Munif Chatib: 2009, 5). Masalah generasi muda saat ini sangat mencemaskan, karena akan membuat sebuah bangsa tenggelam sedikit demi sedikit. Karakter dan kualitas anak bangsa Indonesia sangat memprihatinkan dengan adanya masalah kemerosotan moral, di antaranya:

1. Meningkatnya kekerasan di kalangan remaja (Reni Akbar Hawadi: 2004,167)

2. Mudah dan ringannya penggunaan bahasa dan kata-kata kasar. (Deddy Mulyana dan Idi Subandy Ibrahim: 1997, 214)

3. Hilangnya rasa empati anak kepada orang lain.

4. Ketidakjujuran yang membudaya. (Doni Koesoema, 2010: 22)

Akar dari masalah krisis karakter ini cukup banyak masalahnya, yang terpenting di antaranya adalah karena longgarnya pegangan terhadap agama; pembinaan moral yang dilakukan oleh orangtua, sekolah, dan masyarakat sudah kurang efektif; kebiasaan orangtua memberikan keteladanan yang baik kurang banyak dilakukan; derasnya arus budaya materialistik, hedonistik dan sekularistik.(Abuddin Nata, 2007: 218)

Pada saat ini pendidikan karakter tidak bisa lagi untuk tidak diindahkan keberadaannya karena peran yang sangat penting untuk memperbaiki moral dan akhlak anak, karena moral anak bangsa saat ini semakin jauh dari kata baik dengan teriringnya zaman modern yang penuh digeluti teknologi informasi yang semakin hari berkembang pesat terus adanya perbaharuan. Berdasarkan uraian di atas dipertimbangkan perlu diadakan kegiatan penyuluhan pendidikan karakter sebagai pilar dalam membangun moral dan akhlak anak di masyarakat sekitar Palangkaraya, terutama wilayah sekitar PKBM Luthfillah di kel. Pahandut yang masih minim pengetahuan mengenai pendidikan umum, agama, dan minimnya kesadaran akan pentingnya pendidikan karakter sehingga maih banyak ditemukan dari anak-anak kecil dan remaja yang tidak mengenyam pendidikan formal ataupun pendidikan kesetaraan.

\section{PERMASALAHAN}

Dalam kegiatan PKM kali ini, untuk mengatasi permasalahan yang tampak, tim Dosen Prodi PAI menawarkan pelaksanaan PKM dengan bentuk Penyuluhan Pendidikan Karakter Sebagai Pilar Dalam Membangun Moral Dan Akhlak Anak yang diadakan di PKBM Luthfillah, yang dibuka untuk peserta PKBM dan umum.

\section{TUJUAN}

Adapun tujuan dari kegiatan PKM ini adalah sebagai berikut:

1. Dapat memahami terhadap pentingnya pendidikan karakter anak 
2. Dapat memahami komunikasi interpersonal antara orang tua dan anak yang ideal

3. Dapat memberikan bimbingan yang nyata terhadap anak terkait dengan moral dan akhlak yang baik.

4. Dapat mengaplikasikan metode dan strategi yang cocok dalam penanaman karakter dalam kehidupan sehari-hari

Mengingat banyak masyarakat yang tidak mengenyam pendidikan formal ataupun kesetaraan, maka penyuluhan ini diharapkan bisa bermanfaat dan membekali masyarakat sekitar mengenai pemahaman akan tuntunan Islam dalam mendidik anak di rumah secara umum dan mengenai tata cara pelaksanaan pendidikan karakter Islami secara personal yang dapat diupayakan secara maksimal oleh tiap anggota keluarga, baik kepala keluarga maupun wakil dan seluruh anggotanya, sehingga dapat membantu pemerintah dalam mensosialisasikan pendidikan karakter bagi masyarakat grass root dalam tataran praktek.

\section{METODE PELAKSANAAN}

\section{Waktu dan Tempat}

Lokasi PKBM Luthfillah ini terletak di jalan Rindang Banua, Gang Manggis, Kel Pahandut, Kec. Pahandut. Daerah ini juga dikenal dengan sebutan Puntun, terletak di pingiran sungai Kahayan, merupakan pemukiman padat dengan kondisi tempat tinggal terbuat dari kayu dalam bentuk rumah panggung. Lokasi ini dapat dikategorikan sebagai pemukiman padat dengan akses jalan jembatan kayu untuk memudahkan transportasi yang hanya dapat dilalui kendaran roda dua dan tiga saja.
Pemukiman padat di Rindang Banua ini sangat diminati masyarakat, dikarenakan letak geografisnya yang dekat dengan seluruh fasilitas umum seperti pasar, puskesmas, sekolah, dan tempat ibadah. Atas dasar kondisi inilah, pada Juli 2004 tumbuh tekad dari sekelompok anak muda untuk mendirikan wadah belajar yang mampu memberikan kesempatan warga masyarakat sekitar Rindang Banua Kelurahan Pahandut Kecamatan Pahandut Kota Palangka Raya Provinsi Kalimantan Tengah untuk memberikan layanan pembelajaran yang diberi nama "Luthfillah" yang bermakna Kelembutan Allah SWT.

Pada awal berdirinya PKBM "Luthfillah" masih meminjam dan menempati bangunan milik Dinas Sosial. Namun, dengan semangat swadaya pada tahun 2005 akhir, PKBM "Luthfillah" berhasil mendirikan sebuah bangunan semi permanen dengan luas $900 \mathrm{~m} 2$ yang beralamat di jalan Rindang Banua Gg. Manggis No. 26-33 RT. 03 RW. XXVI Kelurahan Pahandut Kecamatan Pahandut Kota Palangka Raya Kalimantan Tengah.

Secara bertahap dengan segala keterbatasan dan dukungan sumber daya yang ada, PKBM Lutfillah terus mengembangkan berbagai layanan pendidikan. Cukup banyak layanan program pendidikan nonformal yang dilakukan antara lain Program Pendidikan Anak Usia Dini (PAUD) dan Kesetaraan. PKBM ini menyediakan bacaan bagi masyarakat yang ingin menambah pengetahuan melalui buku bacaan. Keberadaan TBM di PKBM Luthfillah sangat membantu masyarakat di lingkungan PKBM, khususnya untuk peserta didik tanpa harus mengeluarkan biaya mahal. 
Untuk meningkatkan keterampilan peserta didik, PKBM melakukan latihan pemanfaatan kain perca, daur ulang kertas, limbah gelas air mineral dan botol plastik, komputer, service HP, tata kecantikan, tata boga, sulam pita, sablon digital. Yang paling membanggakan bagi PKBM Luthfillah adalah pada bulan September 2012, pada puncak peringatan Hari Aksara Intertnasional ke-47 di Palangkaraya, PKBM Lutfillah mendapat penghargaan sebagai Juara Nasional PKBM Berprestasi dari Kementerian Pendidikan dan Kebudayaan Republik Indonesia

Untuk dapat menuju ke PKBM Luthfillah Palangkaraya ini bisa menggunakan mobil, akan tetapi untuk memasuki ke lokasi, harus menggunakan motor, atau berjalan kaki namun agak jauh, dikarenakan jalan gang yang sempit. Bila ditempuh dari kampus UM Palangkaraya, memakan waktu sekitar 20 menit.

\section{METODE KEGIATAN}

Adapun metode yang akan digunakan dalam kegiatan PKM mendatang tersebut adalah metode ceramah, dialog aktif dan diskusi guna mencari pemecahanan dari masalah yang tengah dihadapi masyarakat yang berkaitan dengan tema di atas. Dengan bantuan video dan media Lcd, diharapkan pemaparan dapat lebih dipahami peserta dan dapat ditarik kesimpulannya untuk kemudian diterapkan bersama, sehingga dapat membantu meminimalisir ketidakseimbangan antara hak dan kewajiban anak serta orangtua dalam hal pendidikan.

\section{HASIL DAN PEMBAHASAN}

Dalam penyelenggaraan kegiatan PKM di PKBM Luthfillah oleh tim dosen PAI tahun 2016 kali ini, menggunakan beberapa metode yang dapat diklasifikasikan sebagai berikut. Berdasarkan teknik komunikasi, metode penyuluhan yang digunakan oleh tim dosen PAI tahun 2016 adalah komunikasi langsung (direct communication) sekaligus komunikasi tidak langsung (indrect communication), yaitu publikasi dalam bentuk undangan, materi print-out, dan pertunjukan mini-video.

Berdasarkan jumlah sasaran yang dicapai, metode penyuluhan tidak menggunakan pendekatan perorangan dengan kunjungan rumah, surat-menyurat, dan hubungan telepon menginat terbatasnya tenaga dan waktu, akan tapi digunakan pendekatan kelompok yaitu dengan digelarnya diskusi kelompok. Berdasarkan media yang digunakan, maka metode penyuluhan kali ini menggunakan media lisan dan media terproyeksi, berupa gambar dan atau tulisan lewat: slide ppt, dan pertunjukan mini video dengan durasi singkat.

Secara garis besar, kegiatan ini seluruhnya dilakukan melalui beberapa tahap yakni:

1. Tahap pertama, pada hari Sabtu bertepatan dengan tanggal 17 Oktober 2015 ketua tim melakukan observasi awal ke PKBM Luthfillah Kel Pahandut Kec Pahandut untuk melihat keadaan dan situasi, apakah benar-benar memungkinkan untuk dilakukan PKM oleh tim dosen PAI dengan grand theme kependidikan Islam. Observasi ini juga untuk berkomunikasi dengan pihak Ketua PKBM, Ibu Khairia Ulfah, M.Pd untuk membicarakan tahap awal 
mengenai rencana penyuluhan pendidikan, rancangan kegiatan, peserta, serta melihat langsung sarana dan prasarana.

2. Tahap Kedua tim PKM menyusun proposal pengabdian kepada masyarakat sesuai dengan RIP yang sudah ditentukan oleh pihak LP2M, sehingga jatuhlah kepada judul Penyuluhan Pendidikan Karakter Sebagai Pilar dalam Membangun Moral dan Akhlak Anak. Setelah proposal selesai, maka proposal pun diajukan dan diserahkan ke pihak LP2M UM Palangkaraya untuk diseleksi.

3. Tahap Ketiga, setelah proposal PKM selesai dan dinyatakan lolos seleksi oleh pihak LP2M UM Palangkaraya, maka pihak LP2M UM Palangkaraya mengeluarkan dana bantuan pada bulan November yang ditetapkan dengan Surat Perjanjian Penugasan Pelaksanaan Pengabdian Masyarakat No: 456/PTM.63.R10/LP2M/P/2015 Tanggal 25 November 2015.

4. Tahap Keempat adalah Persiapan Kegiatan PKM yang terdiri dari menentukan tanggal yang sesuai, memperkaya referensi buku dan materi yang berhubungan dengan pendidkan karakter Islami, menentukan pemateri sesuai bidang keahliannnya, mengkalkulasikan biaya yang dibutuhkan, menyususn draf tentatif acara, para petugas acara, serta mengurus beberapa persiapan teknis pra-acara.

5. Tahap Kelima adalah sosialisasi kegiatan kepada para calon peserta penyuluhan PKBM Luthfillah melalui guru dan tenaga pendidik setempat.

6. Tahap Keenam adalah pelaksanaan kegiatan penyuluhan pendidikan karakter di PKBM Luthfillah pada hari Senin 28 Maret 2016 yang diisi juga dengan tanya jawab dan diskusi serta diakhiri dengan evaluasi program secara tertulis melalui angket yang berisi kepuasan dan saran.

Khalayak sasaran kegiatan ini adalah para masyarakat Puntun dan guru atau tutor setempat yang berjumlah 60 peserta, yang terdiri dari masyarakat sekitar PKBM Luthfillah 40 orang dan 13 orang guru, campur antara kaum ayah dan kaum ibu. Dari 60 undangan yang tersebar, ada 53 peserta yang memenuhi undangan dan berkesempatan hadir dalam acara PKM yang dilakukan pada Senin 28 Maret 2016. Acara berlangsung selama 3 jam yang dipandu oleh Siti Aisyah, S.Pd.I. Acara diawali dengan pembukaan oleh Ketua LP2M UM Palangkaraya yang diwakili oleh Ka. Prodi PAI Supriadi, M.Pd.I, dan prakata dari Sekretaris PKBM Luthfillah Nor Aisyah, M.Pd.I. Acara kemudian dilanjutkan dengan kalam ilahi oleh A. Alghifari F, M.Pd.I dan acara inti, yakni penyuluhan dan diskusi yang dimoderatori oleh Nurul Husna Y, M.Pd.I.

Pemateri pertama adalah Supriadi, M.Pd.I., dilanjutkan dengan pemateri kedua Muhammad Tri Ramdhani, M.Pd.I. dan dilanjutkan dengan pemateri ketiga Hunainah, Lc., MA. Kemudian acara disambung dengan tanya jawab dan diskusi lalu diakhiri dengan penutup. Tidak lupa pula sebelum penutup tiap peserta diminta sumbangsih kritik atas acara yang telah berlangsung dan saran untuk acara PKM selanjutnya.

Dalam program pelaksanaan Pengabdian Kepada Masyarakat dengan judul Penyuluhan Pendidikan Karakter Sebagai Pilar dalam Membangun Moral dan Akhlak Anak yang bertempat di PKBM Luthfillah Kel. Pahandut Kec. 
Pahandut, Palangka Raya pada Senin 28 Maret 2016, tercatat telah hadir 53 peserta yang terdiri dari 13 guru dan tutor PKBM Luthfillah, serta 40 wali murid dari PAUD Luthfillah, dan walimurid dari kelas kesetaraan PKBM Luthfillah.

Kehadiran peserta sebanyak $88 \%$ menandakan antusias masyarakat sekitar PKBM Luthfillah Kel. Pahandut Kec. Pahandut, Palangka Raya untuk mengikuti program PKM kali ini yang dilakukan oleh tim dosen prodi PAI UM Palangkaraya. Sebelumnya, belum ada kegiatan PKM sejenis yang dilakukan, baik dari tim dosen atau yang dilakukkan dosen secara mandiri, dari universitas/perguruan tinggi manapun. Untuk itu, ketua PKBM Luthfillah Kel. Pahandut Kec. Pahandut, Palangka Raya menyampaikan penghargaan ini pada sambutan di awal acara pembukaan PKM.

Adapun pada inti acara, sebanyak 5 orang peserta yang bertanya mengenai pelaksanaan pendidikan karakter, baik yang dapat diupayakan oleh pihak sekolah, masyarakat, ataupun yang bisa dilakukan oleh tiap keluarga muslim sebagai unit terkecil dari suatu bangsa. Selain itu, sebanyak 5 orang yang menanggapi secara langsung tentang proses berlangsungnya program PKM ini. Hal ini mengindikasikan bahwa acara berjalan lancar dan para peserta memahami dengan baik point yang disampaikan pemateri, bahkan menanggapi dengan positif program PKM kali ini.

Dari 53 peserta, 34 orang yang telah bersedia melakukan umpan balik tertulis, yakni dengan mengisi lembar kuesioner evaluasi program serta kritik dan saran membangun yang telah disediakan panitia. Hal ini bermakna bahwa sebanyak $64 \%$ peserta telah memberikan pendapat mereka dan membantu evaluasi program PKM kali ini dan tidak lupa memberikan catatan penting untuk perbaikan pada masa mendatang. Sedangkan sisanya menyampaikan umpan balik secara lisan, mengingat para guru sebagai tuan rumah, sibuk membantu mengurus acara dan membereskan tempat selepas acara selesai.

Berdasarkan pada kegiatan yang dilaksanakan hari Senin 28 Maret 2016, dapat diperoleh hasil dari kegiatan ini dengan adanya kontribusi yang diberikan oleh masyarakat yaitu antusiasnya mereka dalam mengikuti kegiatan penyuluhan ini, karena yang telah dikemukakan di awal pada BAB I bahwasannya masyarakat di daerah tersebut masih minimnya pengalaman dan pengetahuan tentang mendidik anak sehingga mereka dibiarkan tumbuh dan berkembang di tempat yang terus menerus jauh dari kata baik dalam hal pendidikan. Dalam kata lain, masyarakat di sana jiwanya haus akan ilmu pengetahuan yang pada dasarnya akan merubah pemikiran mereka menjadi orang yang lebih baik lagi, sehingga mereka dapat secara langsung merasakan manfaat dari kegiatan penyuluhan tentang pendidikan karakter tersebut. Dalam kuesioner evaluasi program PKM kali ini yang telah dibagikan, banyak audiens yang mewasiatkan agar kegiatan pendidikan semacam ini bisa digelar pada moment yang lain agar mereka selalu dapat tercerahkan dan mendapat pengetahuan yang baru, meski mereka tidak sempat mengenyam pendidikan formal atau ikut serta kelas parenting yang berbayar. 


\section{SOLUSI YANG DITAWARKAN}

Setelah tim dosen PKM PAI menerima kuesioner evaluasi program serta saran dan masukan untuk kegiatan PKM selanjutnya, ditambah lagi saran dari guru dan pihak PKBM Luthfillah, maka didapatkan dukungan positif dari pihak PKBM Luthfillah secara khusus dan dari pihak masyarakat kel. Pahandut kec. Pahandut secara umum. Dari beberapa saran yang masuk, dapat dipahami bahwa pihak PKBM Luthfillah menginginkan adanya pelatihan dan sosialisasi pada masa mendatang dengan tema pendidikan enterpreneur untuk meningkatkan ekonomi masyarakat. Sedangkan masukan dari masyarakat sekitar adalah untuk mengadakan kegiatan semacam ini, yang berkaitan dengan pendidikan agama dengan bentuk berbeda, seperti praktek atau dalam bentuk lain, dengan tema semisal "Gaya dan Pola Asuh Anak serta Remaja" atau "Pelatihan Manajemen Pendidikan Anak dan Perlindungan Anak" atau "Keseimbangan antara Hak dan Kewajiban Anak dan Orangtua".

Beranjak dari hal di atas, maka tim dosen PKM PAI berniat untuk mengadakan kegiatan "Keseimbangan antara Hak dan Kewajiban Anak dan Orangtua" pada tahun mendatang, bila masih diamanahkan untuk dapat berperan aktif, untuk turut serta mewarnai kegiatan PKM dosen di lingkungan UM Palangkaraya, di bawah payung LP2M UM Palangkaraya.

Urgensi kegiatan tersebut dikarenakan bahwa anak memiliki tugas dan kewajibannya terhadap orangtua, namun di samping itu, sebagai warga negara, ia memiliki hak untuk mengenyam pendidikan yang layak, apapun kedudukan ekonomi keluarganya. Telebih lagi di mata Islam, anak adalah amanah Allah Swt. yang tentu harus dijaga dan dirawat dengan pendidikan yang baik dan Islami sehingga nanti tidak hanya akan menjadi qurratu a'yun bagi kedua orangtuanya namun juga menjadi bibit unggul generasi bangsa. Dalam perspektif Islam, anak tidak seyogyanya dibiarkan tumbuh liar begitu saja, sehingga akan banyak stimulus eksternal yang mempengaruhinya, sedangakan sang anak tidak memiliki benteng yang cukup kuat. Hal ini tidak hanya hanya berimplikasi negatif pada dirinya, orangtua, dan keluarga, akan tapi akan merambah kepada kerusakan generasi dan masyarakat sekitar. Hal tersebut harusnya tidak berhenti pada kajian normatif. Akan tapi pada tataran realita, banyak ketidakseimbangan terjadi.

\section{SIMPULAN DAN SARAN}

\section{SIMPULAN}

Mendidik anak yang baik dan sesuai dengan value Islami tentu memerlukan pengetahuan yang cukup, tidak hanya berdasarkan pengalaman yang turun-temurun warisan nenek moyang belaka. Apalagi bila mengutip kata hikmah dari Ali bin Abi Thalib ra. yang mewasiatkan para orangtua muslim, "Didiklah anakmu untuk masa yang bukan masamu." Seiring dengan ilmu psikilogi pendidikan yang berkembang, para pakar dan ahli banyak merumuskan langkah dan cara menumbuhkembangkan karakter positif anak. Seperti yang disampaikan praktisi dan founder dari pendidikan karakter.com, Timothy Wibowo dalam bukuntya "7 Hari Membentuk Karakter Anak" dan buku yang berjudul "Succes Begin with 
Character". Selain itu Hamdai Hamid dan Beni Ahmad Saebani dalam bukunya "Pendidikan Karakter Perspektif Islam" juga Zainal Aqib dalam "Pendidikan Karakter di Sekolah." Buku-buku tersebut jarang terjamah masyarakat awam, maka tim PKM prodi Pendidikan Agama Islam kali ini mengangkat sebagian cara-cara yang digariskan sang ahli dan mengetengahkan dalam diskusi dengan singkat dan padat sehingga masyarakat dapat memetik juga manfaat terkait.

Pada awal pelaksanaan, pihak PKBM Luthfillah bersama dengan Ketua, turut membantu menyiapkan tempat dan sarana yang dibutuhkan dalam keberlangsungan acara, seperti Lcd, kecukupan meja dan kursi, tata ruang, dan lainnya. Di tengah jalannya acara, mereka juga membantu ketertiban dan kondusif keberlangsungnya acara. Selain itu juga ketika proses materi berlangsung sudah terasa mulai adanya interaksi dan diskusi kecil serta dialog dengan tanggapan positif oleh penyaji.

Setelah acara selesai, para peserta membantu tim dosen PKM dalam merapikan kembali ruangan dan membersihkan sisa konsumsi yang tercecer.

\section{SARAN}

Setelah tim dosen PKM PAI menerima kuesioner evaluasi program serta saran dan masukan untuk kegiatan PKM selanjutnya, ditambah lagi saran dari guru dan pihak PKBM Luthfillah, maka didapatkan dukungan positif dari pihak PKBM Luthfillah secara khusus dan dari pihak masyarakat kel. Pahandut kec. Pahandut secara umum. Dari beberapa saran yang masuk, dapat dipahami bahwa pihak PKBM Luthfillah menginginkan adanya pelatihan dan sosialisasi pada masa mendatang dengan tema pendidikan enterpreneur untuk meningkatkan ekonomi masyarakat. Sedangkan masukan dari masyarakat sekitar adalah untuk mengadakan kegiatan semacam ini, yang berkaitan dengan pendidikan agama dengan bentuk berbeda, seperti praktek atau dalam bentuk lain, dengan tema semisal "Gaya dan Pola Asuh Anak serta Remaja" atau "Pelatihan Manajemen Pendidikan Anak dan Perlindungan Anak" atau "Keseimbangan antara Hak dan Kewajiban Anak dan Orangtua".

Beranjak dari hal di atas, maka tim dosen PKM PAI berniat untuk mengadakan kegiatan "Keseimbangan antara Hak dan Kewajiban Anak dan Orangtua" pada tahun mendatang, bila masih diamanahkan untuk dapat berperan aktif, untuk turut serta mewarnai kegiatan PKM dosen di lingkungan UM Palangkaraya, di bawah payung LP2M UM Palangkaraya.

Urgensi kegiatan tersebut dikarenakan bahwa anak memiliki tugas dan kewajibannya terhadap orangtua, namun di samping itu, sebagai warga negara, ia memiliki hak untuk mengenyam pendidikan yang layak, apapun kedudukan ekonomi keluarganya. Telebih lagi di mata Islam, anak adalah amanah Allah Swt. yang tentu harus dijaga dan dirawat dengan pendidikan yang baik dan Islami sehingga nanti tidak hanya akan menjadi qurratu a'yun bagi kedua orangtuanya namun juga menjadi bibit unggul generasi bangsa. Dalam perspektif Islam, anak tidak seyogyanya dibiarkan tumbuh liar begitu saja, sehingga akan banyak stimulus eksternal yang mempengaruhinya, sedangakan sang anak tidak memiliki benteng yang cukup kuat. Hal ini tidak hanya hanya berimplikasi negatif pada dirinya, 
orangtua, dan keluarga, akan tapi akan merambah kepada kerusakan generasi dan masyarakat sekitar. Hal tersebut harusnya tidak berhenti pada kajian normatif. Akan tapi pada tataran realita, banyak ketidakseimbangan terjadi.

Adapun metode yang akan digunakan dalam kegiatan PKM mendatang tersebut adalah metode ceramah, dialog aktif dan diskusi guna mencari pemecahanan dari masalah yang tengah dihadapi masyarakat yang berkaitan dengan tema di atas. Dengan bantuan video dan media Lcd, diharapkan pemaparan dapat lebih dipahami peserta dan dapat ditarik kesimpulannya untuk kemudian diterapkan bersama, sehingga dapat membantu meminimalisir ketidakseimbangan antara hak dan kewajiban anak serta orangtua dalam hal pendidikan.

\section{UCAPAN TERIMA KASIH}

Ucapan terima kasih disampaikan kepada Universitas Muhammadiyah Palangkaraya yang telah membantu pendanaan pembiayaan kegiatan pengabdian kepada masyarakat pada tahun anggaran 2015. Terima kasih juga disampaikan kepada pihak pimpinan PKBM Luthfillah dan seluruh staf serta pihak lainnya yang secara aktif berpartisipasi pada kegiatan penyuluhan ini.

\section{DAFTAR PUSTAKA}

Semma, Mansyur, Negara dan korupsi: Pemikiran Mochtar Lubis atas Negara, Manusia Indonesia, dan Perilaku Politik, Jakarta: Yayasan Obor Indonesia, 2008

Hawadi, Reni Akbar dkk, Bimbingan dan Konseling di Institusi Pendidikan, Yogyakarta: Media Abadi, 2004

mulyana, Deddy, IImu Komunikasi:Suatu Pengantar, Remaja Rosdakarya, 2013

Koesuma, Doni, Pendidikan Karakter: Strategi Mendidik Anak Dizaman Global, Jakarta: Grasindo, 2010

Chatib, Munib, Sekolahnya Manusia, Bandung: Kaifa Farhana, 2009

Nata, Abuddin, Manajemen Pendidikan, Mengatasi Kelemahan Pendidikan Islam di Indonesia, Jakarta: Kencana Prenada Media Group, 2013 